\title{
The Implementation of Multiple-Representation Approaches Based on E-Module to Reduce Misconceptions of Prospective Physics Teachers During the Covid-19 Pandemic
}

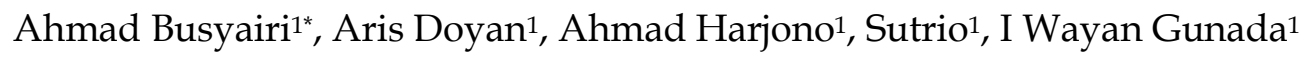 \\ ${ }^{1}$ Physics Education, FKIP, University of Mataram, Mataram, Lombok, West Nusatenggara, Indonesia
}

DOI: $\underline{10.29303 / \text { ippipa.v7iSpecialIssue. } 970}$

\section{Article Info}

Received: September 9th, 2021

Revised: November 30th 2021

Accepted: December 3rd, 2021

\begin{abstract}
One of the problems that are often found in universities, especially in physics subjects, is the existence of misconceptions in students (learners). This study aims to determine the effectiveness of using the multiple-representation approach Based on EModule in reducing the misconceptions of prospective physics teachers during the Covid19 pandemic. The method used is quantitative research with a one-group pretest-posttest design. The sample consisted of 25 prospective physics teachers at one of the universities in the city of Mataram. The instrument used in this research is an open-ended three-tier test. A total of 10 test items with 30 questions were used in this study. The test was given twice, namely before and after treatment. The test results data were then analyzed using descriptive statistics to determine the decrease in the percentage of students who experienced misconceptions. Based on the results of data analysis shows that there is a decrease in the percentage of students who experience misconceptions by $31.89 \%$ from the initial number of 57.19 to $25.30 \%$. This decrease in misconceptions was also followed by an increase in the percentage of students who understood the concept from 18.14 to $72.38 \%$. Thus, it can be concluded that the application of the multiple representation approach assisted by E-Modules can be used as an alternative to reduce misconceptions and improve understanding of the concept of prospective physics teachers in the COVID-19 pandemic.
\end{abstract}

Keywords: Multiple Representations; E-Modules; Misconceptions; Prospective Physics Teachers; Covid-19

Citation: Busyairi, A., Doyan, A. ., Harjono, A. ., Sutrio, S., \& Gunada, I. W. (2021). The Implementation of MultipleRepresentation Approaches Based on E-Module to Reduce Misconceptions of Prospective Physics Teachers During the Covid-19 Pandemic. Jurnal Penelitian Pendidikan IPA, 7(SpecialIssue), 158-167. https://doi.org/10.29303/jppipa.v7iSpecialIssue.970

\section{Introduction}

Physics is a branch of Natural Sciences that studies natural phenomena related to matter and energy. These natural phenomena are further simplified by experts in the form of concepts, theories, and laws so that they can be easily accepted by the human mind (Kaniawati, 2017; Doyan et al., 2018). Through concepts, one can simplify his thinking by using one term for several events related to one another (Ismet, 2013). The term is used to represent a more complex reality. For example, the concept of distance is a term to describe the reality of the length of the path traversed by a moving object. Likewise, the concept of speed is used to explain the reality of the magnitude of the distance traveled by objects per unit of time.

A person's understanding of a particular concept is called a conception (Suparno, 2005). The fact, Everyone's conception of a certain concept can be different. Therefore, in the classroom, we will get to know the conception of scientists, teachers' conceptions, students' conceptions, and so on.

\footnotetext{
*Email: ahmad.busyairi@unram.ac.id
} 
However, the conception of scientists or experts is seen as the most correct or most widely accepted and recognized conception (Hikmawati, \& Sutrio, 2019). Conceptions that are not by scientific conceptions are generally called misconceptions.

The misconception is a term that indicates a difference in understanding between the concepts that students have and concepts determined by experts (Solas \& Wilson, 2017; Samsudin et al., 2017; Fratiwi et al., 2017; Osman et al., 2017; McLaughlin \& MacFadden; 2014). The same thing was expressed by Suparno \& Paul, (2005), and Hikmawati \& Sutrio, (2019) which stated that misconceptions are concepts that are believed to be true by students but are not following the truth of concepts recognized by experts. In other words, students believe the concept they have is correct but in fact, the concept is wrong according to the provisions of the experts.

In general, students' misconceptions can be caused by many factors, one of which is the teacher teaching in the classroom (Barke et al., 2009). Teacher errors in teaching, wrong teacher conceptions, and inadequate teacher understanding can lead to misconceptions in students. Misconceptions caused by teacher errors are usually rather difficult to fix because students feel confident that the concepts given by the teacher are correct. Thus, before teaching, teachers or prospective teachers should master the material that will be taught in class.

In addition, understanding concepts correctly has a very important role in the success of learning physics. Students who understand the concept well will be able to abstract the observed phenomena so that these phenomena can be classified in certain groups appropriately. Vice versa, students who do not understand the concept correctly (misconceptions) will classify phenomena incorrectly which in turn can hinder the achievement of higher cognitive levels (Santrock, 2011; Höft et al., 2019; Bartel et al., 2013). This will affect the low cognitive learning outcomes and problem-solving ability of students (Barmby et al., 2014).

However, based on the results of a preliminary study at one of the universities in the city of Mataram, it shows that there are still many prospective physics teacher students who do not understand the concept and even experience misconceptions. In motion kinematics, there are $59 \%$ of students have misconceptions, $29 \%$ do not understand the concept and only $12 \%$ of students understand the concept. This shows that the approaches, methods, or learning strategies that have been used by lecturers are still not effective in increasing understanding of concepts and reducing misconceptions that occur in students. Therefore, there needs to be another approach or teaching method as an alternative to overcome these problems. One alternative that can be used to reduce the misconceptions of prospective physics teacher students, especially on motion kinematics material, is to use a multiple representation approach.

The multi-representation approach refers to learning that presents the same concept in different formats or forms (Tytler \& Prain, 2013). According to Treagust et al, (2017), multi-representation means representing the same concept in different formats (pictures, verbal, graphs, and mathematics). The purpose of using multiple representations in presenting a physics concept is to be able to clarify a concept which in turn can further improve students' understanding of the concept. This is in line with the statement of Rosengrant et al, (2007) and Rahman et al, (2021) which states that multiple representations can help learn concepts, improve students' critical thinkin and solve problems, and help address problems so as to improve student learning outcomes. Furthermore, Suyono, (2015) emphasizes that the application of multiple representation-based learning is a must, especially for abstract materials that involve the interconnection of natural phenomena. In addition, using various representations is also expected to better accommodate all types of learning style tendencies.

Empirical research related to the use of multiple representations approaches in improving students' understanding of concepts has been done before. The results of research Suhandi \& Wibowo, (2012); Widianingtiyas et al, (2015); Hasbullah et al, (2018); Phanphech et al, (2019); and Kurniasih et al, (2020) show that the application of a multi-representation approach in learning physics can improve students' understanding of concepts. Therefore, here the researchers plan to apply learning based on a multiple representation approach to improve conceptual understanding while reducing the misconceptions of prospective physics teachers, especially related to onedimensional motion kinematics material.

Given the current state of Covid-19, schools or colleges are required to study online. Based on the results of research by several experts, online learning during the current Covid-19 pandemic is still considered ineffective (Basar, 2021; Dewatara \& Nurgiansyah, 2021; Rahma \& Pujiastuti, 2021; and Hatmo, 2021). Therefore, to optimize the learning process that occurs in students, in this study students will also be given E-modules so that they can study independently outside lecture hours. The reason researchers use electronic modules (E-Modules) is that E-Modules are easier to distribute to students when compared to print modules considering the uncertain pandemic conditions. 


\section{Method}

The method used is quantitative research with a one-group pretest-posttest design (Frankel et al., 2012). This study did not use a comparison class but had used a pretest-posttest so that the magnitude of the decrease in the misconceptions of prospective physics teachers after they were given treatment could be known with certainty. The research design can be seen in table 1 .
Table 1. Research design

\begin{tabular}{lll}
\hline Pretest & Treatment & Posttest \\
\hline $\mathbf{x}$ & Multiple-Representation Approach & $\mathrm{x}$ \\
\hline
\end{tabular}

Illustration of learning with multiple representation approach in straight motion with constant acceleration can be seen in figure 1 .

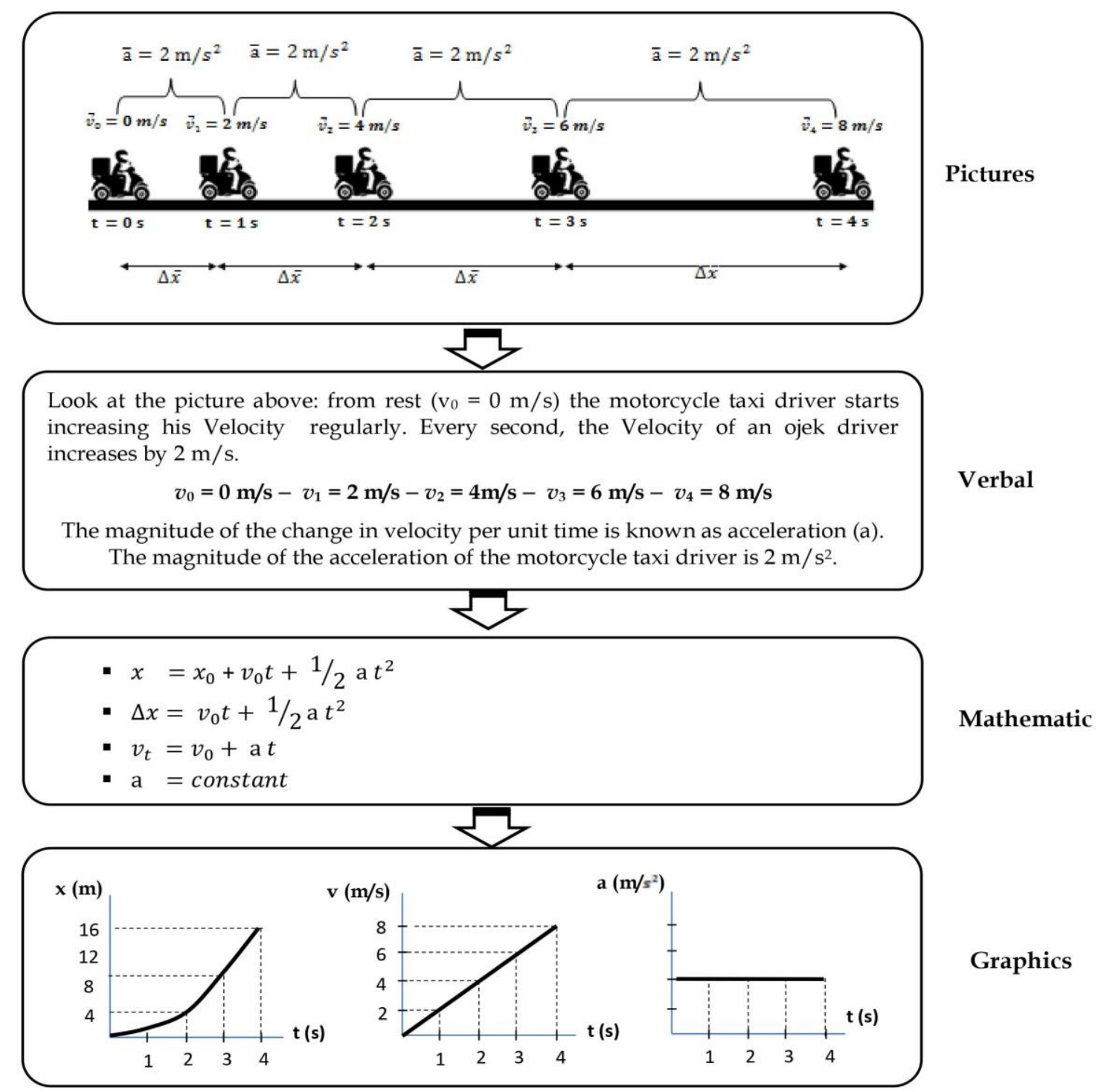

Figure 1. an example of using the Multiple Representation approach in straight motion with constant acceleration

This research was conducted at Maratam University, West Nusa Tenggara, Indonesia. The sample used consisted of 25 prospective physics teachers who were taking the Basic Physics I course. Sampling used a simple random sampling technique. Simple random sampling technique is a technique of taking samples from members of the population which is carried out randomly without regard to the strata that exist in the population (Sugiyono, 2012).

The instrument used in this research is in the form of a three-tier test. A total of 10 test items with 30 questions were used in this study. The test was carried out twice, namely before and after treatment. Before being used, the test instrument is first validated by 
experts. This validation aims to see the suitability between the contents of the instrument and the material that has been taught, the suitability of questions and answers, and the suitability of grammar.

The test results data were then categorized and analyzed using descriptive statistics to determine the percentage of prospective physic teachers who Mastering the concept, misconceptions, guessing or not know the concept. The following is a guideline for categorizing students' conceptions using a three-tier test (Arslan, Cigdemoglu, \& Moseley, 2012).

Tabel 2. The Grouping Criteria of Students' Conception Based on Three-tier Test

\begin{tabular}{lllllll}
\hline Answer & Code & Reason & Code & Conviction & Code & Category \\
\hline True & $\mathrm{T}$ & True & $\mathrm{T}$ & Sure & S & Mastering the concept \\
True & $\mathrm{T}$ & False & $\mathrm{F}$ & Sure & $\mathrm{S}$ & Misconception \\
False & $\mathrm{F}$ & True & $\mathrm{T}$ & Sure & $\mathrm{S}$ & Misconception \\
False & $\mathrm{F}$ & False & $\mathrm{F}$ & Sure & $\mathrm{S}$ & Misconception \\
True & $\mathrm{T}$ & True & $\mathrm{T}$ & Not Sure & NS & Guessing \\
True & $\mathrm{T}$ & False & $\mathrm{F}$ & Not Sure & NS & Not know the concep \\
False & $\mathrm{F}$ & True & $\mathrm{T}$ & Not Sure & NS & Not know the concep \\
False & $\mathrm{F}$ & False & $\mathrm{F}$ & Not Sure & NS & Not know the concep \\
\hline
\end{tabular}

\section{Result and Discussion}

The percentage of prospective physics teachers who Mastering the Concept (MC), Misconception (M),
Guessing (G), and Not Know the Concept (NKC) based on the results of the pretest and posttest on onedimensional motion kinematics material can be seen in Figure 2.

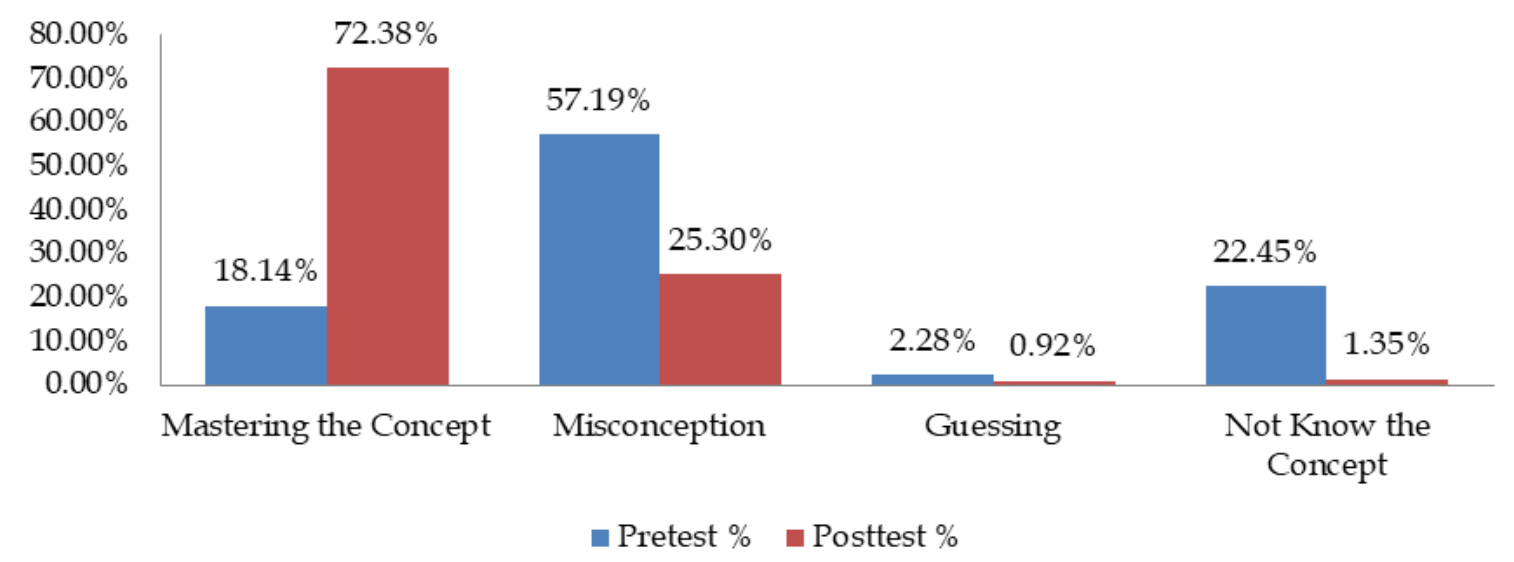

Figure 2. The percentage of the number of prospective physics teachers who are $M C, M, G$, and NKC based on the results of the pretest and posttest

The graph above shows that the percentage of prospective physics teachers who experience misconceptions has decreased by $23.32 \%$. This is followed by the increasing number of students who mastered the concept, which is $46.33 \%$. This indicates that the application of the multiple representation approach assisted by E-Modules can improve understanding of concepts and reduce misconceptions that occur in prospective physics teachers.
Furthermore, for more in-depth analysis, an analysis of the pretest and posttest scores was carried out for each concept in the motion kinematics material. The following is the percentage of the number of prospective physics teacher students who Mastering the Concept (MC), Misconception (M), Guessing (G), and Not Know the Concept (NKC) on the concepts of distance and displacement, velocity, and acceleration in one-dimensional motion kinematics. 


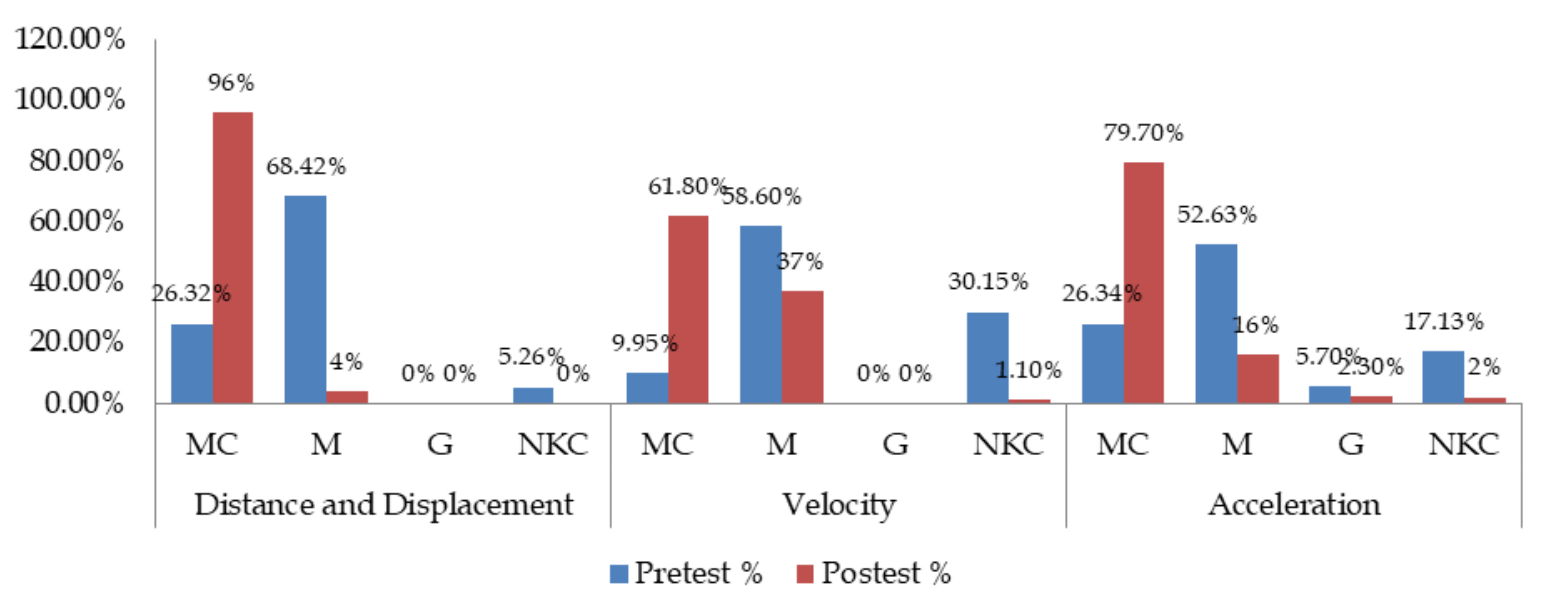

Figure 3. The percentage of the number of prospective physics teachers who are MC, M, G, and NKC for each concept in the one Dimensional Kinematics material

The results of data analysis showed that the number of prospective physics teachers who experienced misconceptions decreased for all concepts in the one-dimensional motion kinematics material (Distance, displacement, velocity, and acceleration). For the concept of distance and displacement, there was a decrease in the percentage of students who experienced misconceptions by $64.22 \%$. Likewise for the concepts of velocity and acceleration, the percentage of students who experienced misconceptions decreased by $21.60 \%$ and $36.63 \%$, respectively. The results of this data analysis indicate that the use of the multiple representation approach assisted by E-Modules can be used as an alternative to reduce misconceptions in all concepts in one-dimensional motion kinematics material.

Furthermore, the following will analyze the misconception patterns of prospective physics teacher students on the concepts of distance and displacement, the concept of velocity, and the concept of acceleration before and after being given treatment.

\section{Distance and displacement}

Based on the pretest score as shown in the graph above ; at first as many as $68.42 \%$ of students experienced misconceptions. Some students are still not able to distinguish between the concepts of distance and displacement. This can be seen from the pattern of their answers when asked the following question:

"If the object's displacement is zero, then it can be ascertained that the object's distance is also zero"

As many as $68.42 \%$ of students believe that the statement is true. They assume that when the object's displacement is zero, the object is at rest so the distance traveled by the object will also be zero. Whereas according to the expert's conception, objects that have zero displacements are not necessarily for a certain period the object is at rest (Giancoli, 2001; Tipler, \& Mosca, 2008; Gordon et al., 2010).

This assumption changed after they were given treatment in the form of applying a multiple representation approach and giving E-Modules. Based on the results of the posttest score analysis, it showed that as many as $96 \%$ of students were able to understand the concept of distance and displacement well although there were still around $4 \%$ of students who had misconceptions. This means that there is a decrease in the percentage of students who experience misconceptions by $64.42 \%$.

In learning by using a multiple representation approach, the concepts of distance and displacement are not only expressed in verbal form but are also visualized in the form of pictures, math, and graphs so that students' understanding of these concepts is more comprehensive. This is what makes students understanding better. The results of this study are in line with the statement of Rosengrant, et.al., (2006) which states that multiple representations can help learn concepts, help solve problems, and help address problems to improve student learning outcomes.

\section{Velocity}

Velocity is a vector quantity. So in addition to having magnitude, velocity also has a direction component. Therefore, in this study, the concept of velocity will be viewed from 3 aspects; (1) the ability to understand the physical meaning of the magnitude of the velocity of an object, (2) the ability to understand the direction of velocity, (3) the ability to identify the velocity of an object from a graph. 
Table 3. Percentage of the number of students who are MC, M, G, and NKC on the Concept of velocity

\begin{tabular}{|c|c|c|c|c|c|c|c|c|}
\hline \multirow{2}{*}{ Velocity Aspect } & \multicolumn{2}{|c|}{ Pretest \% } & \multicolumn{6}{|c|}{ Posttest \% } \\
\hline & MC & $\mathbf{M}$ & $\bar{G}$ & $\overline{\mathrm{NKC}}$ & MC & $\mathbf{M}$ & G & NKC \\
\hline $\begin{array}{l}\text { 1. The ability to understand the physical meaning of the } \\
\text { velocity of an object }\end{array}$ & 5.26 & 63.16 & 0.00 & 31.60 & 64.00 & 36.00 & 0.00 & 0.00 \\
\hline $\begin{array}{l}\text { 2. The ability to understand the direction of the velocity } \\
\text { of an object. }\end{array}$ & 21.10 & 53.00 & 0.00 & 26.30 & 58.00 & 40.00 & 0.00 & 2.00 \\
\hline $\begin{array}{l}\text { 3. Ability to identify the velocity of objects from the } \\
\text { graph. }\end{array}$ & 3.52 & 59.70 & 0.00 & 32.55 & 62.67 & 36.00 & 0.00 & 1.3 \\
\hline Average & 9.95 & 58.60 & 0.00 & 30.15 & 61.80 & 37.00 & 0.00 & 1.10 \\
\hline
\end{tabular}

To find out the prospective physics teacher's conception of the physical meaning of the concept of velocity, they were given questions in the form of a picture of the position of two objects that were moving straight to the right.

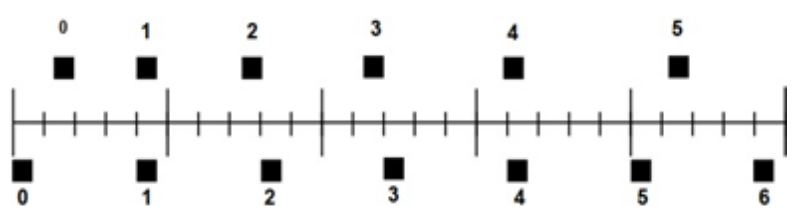

Figure 4. The position of objects every one second

Then they were instructed to determine when the two objects had the same velocity. At first, as many as $63.16 \%$ of students experienced misconceptions in this case and only $5.26 \%$ of students understood the concept. They assume that objects have the same Velocity when the positions of the two objects are the same or parallel (at the 1st and 4th seconds). This indicates that students do not understand the definition of the physical meaning of the concept of Velocity.

Likewise, when prospective physics teachers are asked about the concept of the direction of the velocity of an object that is moving. As many as $53.00 \%$ of students think that when an object initially moves to the right and then slows down until it finally stops, then as long as the object is decelerating the velocity of the object is negative (opposite to the direction of its original velocity).

In addition, the researcher also identified that students had misconceptions in reading graphs. Three graphs are presented which consist of a graph of position versus time $(x-t)$, graph of velocity versus time $(v-t)$, and graph of acceleration versus time $(a-t)$. As many as $59.70 \%$ of students experienced misconceptions in this case. Only $3.52 \%$ of prospective physics teachers understand the concept.

Based on the pattern of answers by the results of the student pretest, the researcher assumed that in the cognitive structure of the students, they could not distinguish between velocity versus time graphs, position versus time graphs, and acceleration versus time graphs. Every graph that has a gradient equal to zero always interprets that the object experiences a constant velocity. Likewise, every graph that decreases they always interpret that the object is slowing down. This can be seen from the pattern of student answers when instructed to determine the type of movement of objects from a graph as shown in figure 5 .

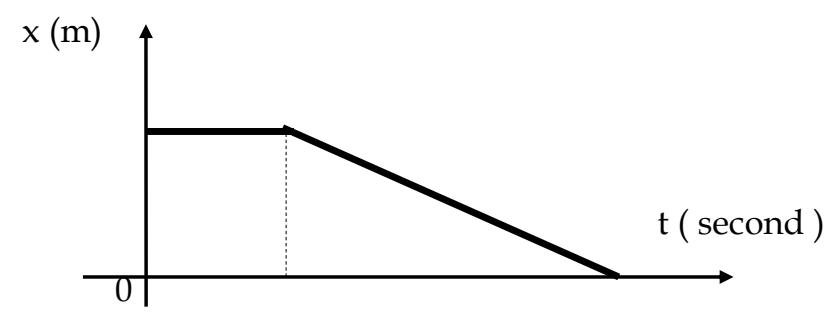

Figure 5. Graph of position as a function of time

As many as $58 \%$ of prospective physics teachers have misconceptions in this case. Most of them think that the graph shows the movement of an object that initially moves at a constant velocity and then slows down until it finally stops. This pattern of answers shows that students still cannot distinguish the type of graph of position versus time $(x-t)$, and graph of velocity versus time $(v-t)$.

This argument is strengthened when looking at the pattern of students' answers when they are instructed to determine when an object experiences a constant velocity based on the figure 6 .

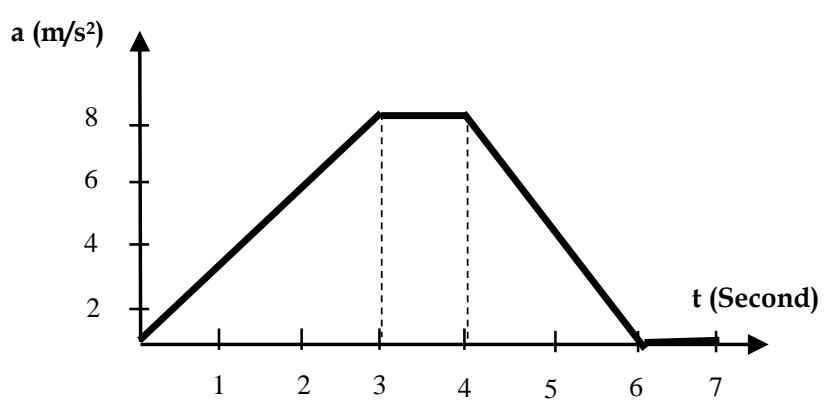

Figure 6. Graph of acceleration as a function of time

As many as $57.90 \%$ of students think that objects move at a constant velocity in the 3rd to 4 th seconds because the gradient of the graph is zero. 
However, after the physics teacher candidates were given treatment, it was seen that there was a decrease in misconceptions on the concept of average speed by $21.60 \%$ (from $58.60 \%$ to $37.00 \%$ ). This shows that the use of multiple representation approaches (pictures, verbal, mathematical, and graphic) is able to reduce misconceptions that occur in students. In addition, the percentage of the number of students who understand the concept also experienced a significant increase of $51.68 \%$. In other words, as many as $21.60 \%$ of students who initially had misconceptions understood the concept, and as many as 30.08 students who initially did not understand the concept became understanding of the concept. This shows that students who initially do not understand the concept more easily experience a conceptual shift towards understanding the concept when compared to students who experience misconceptions.

\section{Acceleration}

Acceleration is a vector quantity. So in addition to having a magnitude of acceleration also has a direction. Therefore, in this study, the concept of acceleration will be viewed from 2 (two) aspects, namely: The ability to understand the physical meaning of the magnitude of the acceleration of an object in relation to the change in velocity and the ability to understand the direction of acceleration.

Tabel 2. Percentage of the number of students who are MC, M, G, and NKC on the Concept of Acceleration

\begin{tabular}{|c|c|c|c|c|c|c|c|c|}
\hline \multirow{2}{*}{ Acceleration Aspect } & \multicolumn{4}{|c|}{ Pretest $\%$} & \multicolumn{4}{|c|}{ Posttest \% } \\
\hline & MC & $\mathbf{M}$ & $\bar{G}$ & NKC & MC & $\mathbf{M}$ & $\bar{G}$ & NKC \\
\hline $\begin{array}{l}\text { 1. Ability to understand the physical meaning of the } \\
\text { magnitude of the acceleration of an object }\end{array}$ & 21.05 & 52.63 & 8.77 & 21.05 & 75.33 & 20.00 & 0.67 & 4.00 \\
\hline $\begin{array}{l}\text { 2. The ability to understand the concept of the direction } \\
\text { of acceleration of an object. }\end{array}$ & 31.58 & 52.63 & 2.63 & 13.20 & 84.00 & 12.00 & 4.00 & 0,00 \\
\hline Average & 26.34 & 52.63 & 5.70 & 17.13 & 79.7 & 16.00 & 2.30 & 2.00 \\
\hline
\end{tabular}

There are four questions given to prospective physics teachers to find out their conception of the concept of acceleration. The first question relates to the definition of acceleration as a change in velocity. When prospective physics teachers are asked:

"If the acceleration of an object is zero, does that mean that the object's velocity is also zero...?"

As many as $68.42 \%$ of prospective physics teachers have misconceptions in this case. They assume that when the acceleration of an object is zero, it means that the object is not accelerating. An object that is not accelerating indicates that the object is at rest so that the object's velocity is also zero.

Similar questions were asked of prospective physics teachers regarding the concept of acceleration as a change in the velocity of an object. The questions are as follows;

"If object $A$ is moving at a higher speed than object $B$, it can be ascertained that object A's acceleration is also higher than object B...?"

A total of $47.40 \%$ of prospective physics teachers have misconceptions in this case. They assume that an object that has a greater speed must have a greater acceleration.

Prospective physics teachers also have difficulty when the concept of acceleration is displayed in the form of pictures. When they are given a picture of the position of two objects that are moving in a straight line to the right.

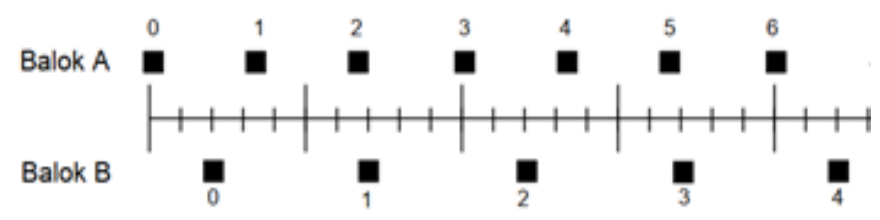

Figure 6. The position of objects every one second interval

As many as $42.00 \%$ of prospective physics teachers have misconceptions in this case and $26.30 \%$ of them do not understand the concept. They assume that the acceleration of block $\mathrm{B}$ is greater than the acceleration of block A.

The three answer patterns, it shows that students experience misconceptions in various forms of representation. However, after the prospective physics teacher experienced the learning process with a multiple representation approach, the number of students who experienced misconceptions, in this case, decreased from the initial $52.63 \%$ to $20.00 \%$. This means that there is a decrease of $32.63 \%$.

Likewise, when we review the ability of prospective physics teachers to understand the concept of the direction of acceleration of an object. At first, as many as $52.63 \%$ had misconceptions in this case. They assume that the direction of acceleration is always the same as the direction of the object's velocity. However, after being given treatment, there was a decrease in the 
percentage of prospective physics teachers who had misconceptions by $40.63 \%$.

Based on the results of the data analysis and discussion above, it can be seen that the application of the E-module-assisted multiple representation approach, in general, can improve understanding of concepts and reduce misconceptions of prospective physics teachers, especially on one-dimensional kinematics material. The results of this study are in line with The results of research Abdurrahman, et.al., (2011); Suhandi \& Wibowo, (2012); Widianingtiyas, et.al., (2015); Hasbullah, et.al., (2018); Phanphech, et.al., (2019); and Kurniasih, et.al., (2020) show that the application of a multi-representation approach in learning physics can improve learners' understanding of concepts.

\section{Conclusion}

It can be concluded that the use of the multiple representation approach assisted by E-Modules, in general, can be used as alternative learning to improve understanding of concepts and reduce misconceptions of prospective physics teachers, especially in onedimensional motion kinematics material. In this study, the researcher only used one class without using a comparison class. Therefore, it is recommended for further research to use a comparison class to compare the effectiveness of one method, strategy, approach, or learning model to another.

\section{Acknowledgements}

The research team is very grateful to the University of Mataram for funding this research through the 2021/2022 PNBP grant

\section{References}

Arslan, H. O., Cigdemoglu, C., \& Moseley, C. (2012). A Three-Tier Diagnostic Test to Assess Pre-Service Teachers' Misconceptions about Global Warming, Greenhouse Effect, Ozone Layer Depletion, and Acid Rain. International Journal of Science Education, 34 (11), 1667-1686. DOI: 10.1080/09500693. 2012.680618

Barke, H.D., Al Hazari, \& Yitbarek, S. (2009). Misconceptions in Chemistry. Addressing Perceptions in chemical Education. Berlin: Springer. Retrieved from: https://link.springer.com/book/10.1007/978-3540-70989-3\#toc

Barmby, P., Bolden, D., \& Thompson, L. (2014). Understanding and Enriching Problem Solving in
Primary Mathematics. Northwich: Critical Publishing Ltd. Retrieved from: https://www.criticalpublishing.com/asset/9787 9/1/UEPSPM_1_sample.pdf

Bartell, T. G., Webel, C., Bowen, B., \& Dyson, N. (2013). Prospective teacher learning: recognizing evidence of conceptual understanding. Journal of Mathematics Teacher Education, 16(1), 57-79. https://doi.org/10.1007/s10857-012-9205-4

Basar, A. M. (2021). Problematika Pembelajaran Jarak Jauh Pada Masa Pandemi Covid-19: (Studi Kasus di SMPIT Nurul Fajri - Cikarang Barat - Bekasi). Edunesia : Jurnal Ilmiah Pendidikan, 2(1), 208-218. https://doi.org/10.51276/edu.v2i1.112 [Indonesian]

Dewantara, J.A., \& Nurgiansyah, T.H., (2021). Efektivitas Pembelajaran Daring di Masa Pandemi COVID 19 Bagi Mahasiswa Universitas PGRI Yogyakarta. Jurnal Basicedu: Research \& Learning in Elementary Education. 5 (1), 367-375.

doi:

https://doi.org/10.31004/basicedu.v5i1.669

[Indonesian]

Doyan, A., Taufik, M., \& Anjani, R., (2018). Pengaruh Pendekatan Multi Representasi Terhadap Hasil Belajar Fisika Ditinjau Dari Motivasi Belajar Peserta Didik. Jurnal Penelitian Pendidikan IPA, 4(1), 35-45. doi: https://doi.org/10.29303/jppipa.v4i1.99 [Indonesian]

Frankel, J. R., Wallen, N. E. Hyun dan Hellen, H. (2012). How to Design and Evaluate Research in Education. New York: McGraw-Hill.

Fratiwi, N. J., Kaniawati, I., Suhendi, E., Suyana, I., \& Samsudin, A. (2017). The transformation of twotier test into four-tier test on Newton's laws concepts. AIP Conference Proceedings, 1848(1), 50011. https://doi.org/10.1063/1.4983967

Hasbullah, Halim, A., \& Yusrizal, (2018). Penerapan Pendekatan Multi Representasi Terhadap Pemahaman Konsep Gerak Lurus. Jurnal IPA dan Pembelajaran IPA, 2(2), 69-74. doi: https://doi.org/10.24815/jipi.v2i2.11621

Hatmo, S.H.D., (2021). Dampak Pandemi Covid-19 Terhadap Efektivitas Pembelajaran Jarak Jauh Secara Daring. SCHOLARIA: Jurnal Pendidikan dan Kebudayaan, 11 (2), 115-122. Retrieved from: https://ejournal.uksw.edu/scholaria/article/vie $\underline{w} / 4222 / 1775$ [Indonesian]

Hikmawati, \& Sutrio. (2019). Miskonsepsi dalam Fisika. Selong: Garuda Ilmu. [Indonesian]

Höft, L., \& Bernholt, S. (2019). Longitudinal couplings between interest and conceptual understanding in secondary school chemistry: an activity-based perspective. International Journal of Science 
Education,

$41(5)$,

607-627.

https://doi.org/10.1080/09500693.2019.1571650

Ismet. (2013). Dampak Perkuliahan Mekanika Berbasis Multipel Representasi terhadap Kecerdasan Spasial Mahasiswa Calon Guru. Jurnal Pendidikan Fisika Indonesia, $9(2)$.

doi:https://doi.org/10.15294/jpfi.v9i2.3029

[Indonesian]

Kaniawati, I. (2017). Pengaruh Simulasi Komputer Terhadap Peningkatan Penguasaan Konsep Impuls-Momentum Siswa SMA. Jurnal Pembelajaran Sains, 1,(1), 24-26. doi: http://dx.doi.org/10.17977/um033v1i1p2426 [Indonesian]

Kaniawati, I., Fratiwi, N.J., Danawan, A., Suyana, I., Samsudin, Suhendi, E. (2019). Analyzing Students' Misconceptions about Newton's Laws through Four-Tier Newtonian Test (FTNT). Journal of Turkish Science Education, 16 (1), 110$122 . \quad$ Retrieved from: https:// files.eric.ed.gov/fulltext/EJ1265039.pdf

Kurniasih, D., Novia, H., \& Jauhari, A., (2020). Pengaruh Model Pembelajaran Inkuiri Terbimbing Dengan Pendekatan Multirepresentasi Terhadap Peningkatan Penguasaan Konsep Fisika Siswa SMA. Jurnal Pendidikan Fisika dan Fisika Terapan, 1(2), 5-11. doi: http://dx.doi.org/10.22373/p-jpft.v1i2.6619 [Indonesian]

McLaughlin, C. A. \& MacFadden B. J. (2014). At the Elbows of Scientists: Shaping science teachers' conceptions and enactment of inquiry-based instruction. Research in Science Education, 44(6), 927-947. doi: https://doi.org/10.1007/s11165014-9408-Z

Namdar, B., \& Shen, J. (2018). Knowledge organization through multiple representations in a computersupported collaborative learning environment. Interactive Learning Environments, 26(5), 638-653. https://doi.org/10.1080/10494820.2017.1376337

Osman, E., BouJaoude, S. \& Hamdan, H. (2017). An investigation of lebanese G7-12 students' misconceptions and difficulties in genetics and their genetics literacy. International Journal of Science and Mathematics Education, 15(7), 1257$1280 . \quad$ Retrieved from: https:/ / eric.ed.gov/?id=EJ1154243

Phanphech, P., Tanitteerapan, T., dan Murphy, E., (2019). Explaining and Enacting for Conceptual Understanding in Secondary School Physics. Issues in Educational Research, 29(1), 180-204. Retrieved from http://www.iier.org.au/iier29/phanphech.pdf

Rahma, N.A., \& Pujiastuti, (2021). Efektivitas Pembelajaran Daring Matematika Pada Masa
Pandemi Covid-19 Di Kota Cilegon [The Effectiveness Of Mathematics Online Learning During The Covid-19 Pandemic In Cilegon City]. Journal of Holistic Mathematics Education, 5(1), 112. doi:

https://dx.doi.org/10.19166/johme.v5i1.3811 [Indonesian]

Rahman, M. M. ., Doyan, A. ., \& Sutrio, S. (2021). The Effectiveness of Video-Assisted MultiRepresentation Approach Learning Tools to Improve Students' Critical Thinking Ability. Jurnal Penelitian Pendidikan IPA, 7(SpecialIssue), 56-60.

https://doi.org/10.29303/jppipa.v7iSpecialIssue .1063

Rosengrant, D., Etkina, E., \& Heuvelen, A.V., (2007). An Overview of Recent Research on Multiple Representations. GSE, 10 Seminary Place, RutgersUniversity, New Brunswick, NJ 08901. Retrieved

from: https://www.researchgate.net/publication/...Re presentations

Samsudin, A., Suhandi, A., Rusdiana D., Kaniawati I. \& Costu B. (2016). Investigating the Effectiveness of an Active Learning Based-Interactive Conceptual Instruction (ALBICI) on Electric Field Concept. In Asia-Pacific Forum on Science Learning and Teaching, $17 \quad$ (1), 1-41. https://www.eduhk.hk/apfslt/download/v17_i ssue1_files/samsudin.pdf

Santrock, J. (2011). Educational Psychology. 5th ed. New York: McGraw-Hill.

Solas, E. C. \& Wilson, K. (2017). Instructor's use of student-generated annotated concept sketches in formative assessment in general science. Journal of Turkish Science Education, 14(4), 144-161. Doi: https://www.tused.org/index.php/tused/articl e/view/179/135

Sugiyono, (2012). Statistika Untuk Penelitian. Bandung: Alfabeta. [Indonesian]

Suhandi, A., \& Wibowo, F.C., (2012). Pendeketan Multirepresentasi Dalam Pembelajaran UsahaEnergi Dan Dampak Terhadap Pemahaman Konsep Mahasiswa. Jurnal Pendidikan Fisika Indonesia, $\quad 8, \quad 1-7 . \quad$ doi: https://doi.org/10.15294/jpfi.v8i1.1988 [Indonesian]

Sunyono. (2015). Model Pembelajaran Multi Representasi. Yogyakarta: Media Akademi. [Indonesian]

Suparno, \& Paul. (2005). Miskonsepsi dan Perubahan Konsep dalam Pendidikan Fisika. Jakarta: Grasindo.

Treagust, D.F., Duit, R., \& Fischer, H.E., (2017). Multiple Representations in Physics Education. Switzerland: Springer International Publishing. Retrieved from: 
https://link.springer.com/book/10.1007/978-3319-58914-5

Tytler, R., \& Prain, V. (2013). Representation construction to support conceptual change. In S. Vosniadou (ed.) Handbook of research on conceptual change (pp. 560-579). New York: Routledge. Retrieved from: https://www.researchgate.net/publication...cha nge

Widianingtiyas, L., Siswoyo, \& Bakri, F., (2015). Pengaruh Pendekatan Multi Representasi dalam Pembelajaran Fisika Terhadap Kemampuan Kognitif Siswa SMA. Jurnal Penelitian $\mathcal{E}$ Pengembangan Pendidikan Fisika, 1 (1), 31-38, doi: https://doi.org/10.21009/1.01105 [Indonesian] 